\title{
Chemically based interactions and nutritional ecology of Labidus praedator (Formicidae: Ecitoninae) in an agroecosystem adjacent to a gallery forest
}

\author{
André F. M. Monteiro ${ }^{1}$; Edison R. Sujii ${ }^{2}$ \& Helena C. Morais ${ }^{1}$ \\ 1 Programa de Pós-Graduação em Ecologia, Departamento de Ecologia, Instituto de Biologia, Universidade de Brasília. \\ 70910-900 Brasilia, Distrito Federal, Brasil.E-mail: monteiro.andre@gmail.com; morais@unb.br \\ 2 Embrapa Recursos Genéticos e Biotecnologia. Caixa Postal 02372, 70770-900 Brasília, Distrito Federal, Brasil. \\ E-mail: sujii@cenargen.embrapa.br
}

\begin{abstract}
New World army ants species have an important role in structuring invertebrate communities. Labidus praedator (Fr. Smith, 1858) is a generalist top predator that can reduce pest densities in agroecosystems. The aim of this study was to describe behavioral attributes, diet composition and interspecific interactions of the ant L. praedator. We searched for army ant raids using standardized trail-walk surveys and plotted army ants raids positions on an aerial image. We photographed events at swarm raids of $L$. praedator and recorded its diet items in basal columns near bivouacs. Six species from four Ecitoninae genera - Labidus (Jurine, 1807), Nomamyrmex (Borgmeier, 1936), Neivamyrmex (Borgmeier, 1940) and Eciton (Latreille, 1804) - were recorded. Caterpillars dominated the composition of the diet of $L$. praedator. Flowers and diaspores of weeds and aril and flesh of fruits were also transported to bivouacs. One colony stopped foraging after intense rainfall and discrete groups of hundreds of $L$. praedator ants were separated under patches covered by shrubs. Groups of Crotophaginae birds, Sarcophaginae flies and Polistinae wasps followed $L$. praedator swarm raids. We discuss the importance of landscape structure for agroecosystem colonization by Ecitoninae and the existence of chemical opportunism between army ants species through the reuse of unoccupied trails.

KEY WORDS. Army ants; Cerrado; chemical opportunism; diet; swarm followers.
\end{abstract}

RESUMO. Interações de origem química e ecologia nutricional de Labidus praedator (Formicidae: Ecitoninae) em um agroecossistema adjacente a uma mata de galeria. Algumas formigas neotropicais de correição têm um importante papel na estruturação da comunidade de invertebrados. Labidus praedator (Fr. Smith, 1858) como predador generalista de topo pode reduzir as densidades de pragas em agroecossistemas. $O$ objetivo deste estudo foi descrever atributos comportamentais, composição de dieta e interações interespecíficas da formiga Labidus praedator. Nós buscamos as colunas das formigas de correição por meio de amostragens por caminhamento em trilhas padronizadas. Nós plotamos as posições das colunas sobre uma imagem aérea. Nós fotografamos eventos nas frentes de caça de $L$. praedator e registramos os itens alimentares transportados para os bivaques. Seis espécies de quatro gêneros de Ecitoninae - Labidus (Jurine, 1807), Nomamyrmex (Borgmeier, 1936), Neivamyrmex (Borgmeier, 1940) e Eciton (Latreille, 1804) - foram registradas. Lagartas dominaram a composição de dieta de $L$. praedator. Diásporos e flores de ervas daninhas e arilo e polpa de frutos também foram transportados para os bivaques. Uma colônia parou de forragear após chuva intensa e grupos discretos de centenas de $L$. praedator se formaram sob áreas cobertas por arbustos. Grupos de aves da subfamília Crotophaginae e vespas e moscas dos táxons Sarcophaginae e Polistinae seguiram as frentes de caça de $L$. praedator. Discutimos a importância da estrutura da paisagem para colonização de agroecossistemas por Ecitoninae e a existência de oportunismo químico entre formigas de correição no mínimo por meio do reuso de trilhas desocupadas.

PALAVRAS-CHAVES. Cerrado; dieta; formigas de correição; oportunismo químico; seguidores das frentes de caça.

Neotropical army ants are wandering and voracious organisms. Some of its species play an important role in structuring invertebrate communities of Tropical Rainforest (BRADY 2003, Kaspari \& O’Donnell 2003). However, most studies deal with Eciton (Latreille, 1804) species in Central America (Powell $\&$ BAKER 2008). Diversity, natural history and ecosystem service of army ants are aspects that are less understood, particularly in dry and open physiognomies such as Brazilian cerrado or even in agroecosystems.

Mass cooperative raiding - including obligate collective prey location, subduing and transport -, nomadism, reproductive colony fission and dichthadiigynes queens are peculiar traits

Revista Brasileira de Zoologia 25 (4): 674-681, December, 2008 
referred to as "the army ant adaptative syndrome". Its life cycle includes a nomadic phase, during which bivouac site changes on daily basis, and a stationary phase, during which the bivouac last for some weeks in the same place (GoTwald 1995).

Chemical and tactile signals constitute the communication system of army ants (HölLDObler \& Wilson 1990). Odor trails permit within-group coordination in activities such as foraging and emigration (GoTwALD 1995). The duration of army ant trails depends on four factors: the porosity of the substrate on which the trail is deposited; the position of the trail (superficial or subterranean); the type of trail (foraging or emigration trail), and the amount of rainfall to which a trail is subjected (Togerson \& AKre 1970).

In order to escape predation by army ants, arthropods and other animals try to run away of army ant swarm raids. Even so, some of them die captured by some birds, which follow army ants raids (Wrenge et al. 2005, Kumar \& O'DonNell 2007). Actually, several animals follow opportunistically army ant swarm raids, such as butterflies, flies, staphylinid beetles and marmosets (HölLDobler \& Wilson 1990, Martins 2000).

Each Labidus praedator (Fr. Smith, 1858) colony has about a million individuals (Hölldobler \& WiLSON 1990) and use diverse habitats - from open grassland to forests. The activity of L. praedator is correlated with ambient temperature and humidity (Fowler 1979). Substrate temperature seems to be the main limiting factor for the colonization of areas by army ants (with trail abandonment or diversion when temperatures exceed $43^{\circ} \mathrm{C}$ ), although prey availability and suitable nesting sites existence are also relevant factors (Meisel 2006). Labidus praedator did not occur in open sunny coffee plantations and occurred less frequently in shaded coffee than in continuous forest in Panama (RoBerTs et al. 2000a).

If preys are unable to escape massive group predation by army ants or opportunistic predation by swarm followers (Отіs et al. 1986), L. praedator can have a detrimental effect on pests in agroecosystems. However, in order to understand its role in agroecosystems, one needs first to locate, observe and monitor $L$. praedator colonies. The aims of this study were to present a methodology to map Ecitoninae species trails distribution and to describe some aspects of the natural history of L. praedator, namely its diet composition and interspecific interactions with opportunistic predators and parasitoids.

\section{MATERIAL AND METHODS}

This study was done in cultivated plots with cotton, manioc, pineapple, maize or cabbage in an experimental field of the Embrapa Cenargen (15 $43^{\prime} 44^{\prime \prime} \mathrm{S}$ and $\left.47^{\circ} 54^{\prime} 00^{\prime \prime} \mathrm{W}\right)$ in Brasília, Distrito Federal, Brazil. These site borders an area of a gallery forest classified as Cerrado, adjacent to the Paranoá Lake (Ribeiro et al. 2001). Anthropic disturbance on cultivated plots occurs by means of tillage for soil preparation, occasional application of agrochemicals and mechanical mowing of weed strips, formed mainly by Brachiaria sp.
We searched for army ants raiding columns using standardized trail-walk surveys in three transects parallels to a forest edge (400 by $100 \mathrm{~m}$ ). Trail-walk surveys were done during 90 minutes from 04:30 p.m. to 06:00 p.m. local time (or from 05:30 p.m. to 07:00 p.m. during Brasília daylight saving time) at a frequency of at least three days per week from January to July of 2008. Monitoring interactions at the swarm raids of $L$. praedator and checking prey items transported to bivouac were performed from 10:00 a.m. to 04:00 p.m. because they were more frequent at this time interval in the studied area. Items transported by $L$. praedator were identified at least in order or family - with basis on identification manual of agricultural pests (Gallo et al. 2002, SARAN \& Santos 2007, Silvie et al. 2007) and weeds (Lorenzi 1991, 1994, Kissmann \& Groth 1997) counted and preserved in alcohol 70\%. The botanical material was deposited in the Embrapa Cenargen herbarium.

When army ant raiding columns or swarm raids were found in the studied agroecosystem, their position were plotted onto a Google Earth ${ }^{\circledR}$ aerial image. The equivalent Google Maps ${ }^{\circledR}$ image was edited according to the recorded trail positions of different Ecitoninae species. Minimal linear distances between two points of superficial trail were estimated through the proportion between two reference points and this imageaggregated scale (left bottom corner of figure 1). Ecitoninae ant species were photographed, collected and sent for identification by specialists. Voucher series from the collected workers were deposited in the Myrmecology Laboratory collection, Cocoa Research Center, Ilhéus, Bahia State, Brazil (Reference number 5532).

\section{RESULTS}

Fifty-six records of six species of Ecitoninae were obtained. Labidus praedator was the most frequent species (with 37 records), followed by Nomamyrmex esembeckii (Westwood, 1842), and Labidus coecus (Latreille, 1802) (both with seven records), Eciton hamatum (Fabricius, 1781) and Eciton vagans (Olivier, 1792) (both with two records) and Neivamyrmex sp. (Borgmeier, 1940) (one record).

The reuse of trail sections by opportunistic ecitonines was observed particularly in trails of $L$. praedator (four records) and Eciton spp. (two records) (Tab. I and Fig. 1). In four of these records, trail reuse by an opportunistic species occurred between 12 and 48 hours after the trail abandonment by the firstly recorded army ant species. In two of these records, this use occurred about a week after trail was abandoned. In the second case, only about $15 \mathrm{~cm}$ of arcade tunnels were observed rising on the soil surface.

Labidus praedator colonies established bivouacs beside Elaeis guineensis Jacq., 1763 (points 9 e 10 of figure 1) surrounded by Brachiaria sp., in pipelines aboveground and belowground (points 17 of figure 1) in the built area and mainly in abandoned subterranean chambers of leaf-cutting ants (Formicidae: Attini). 


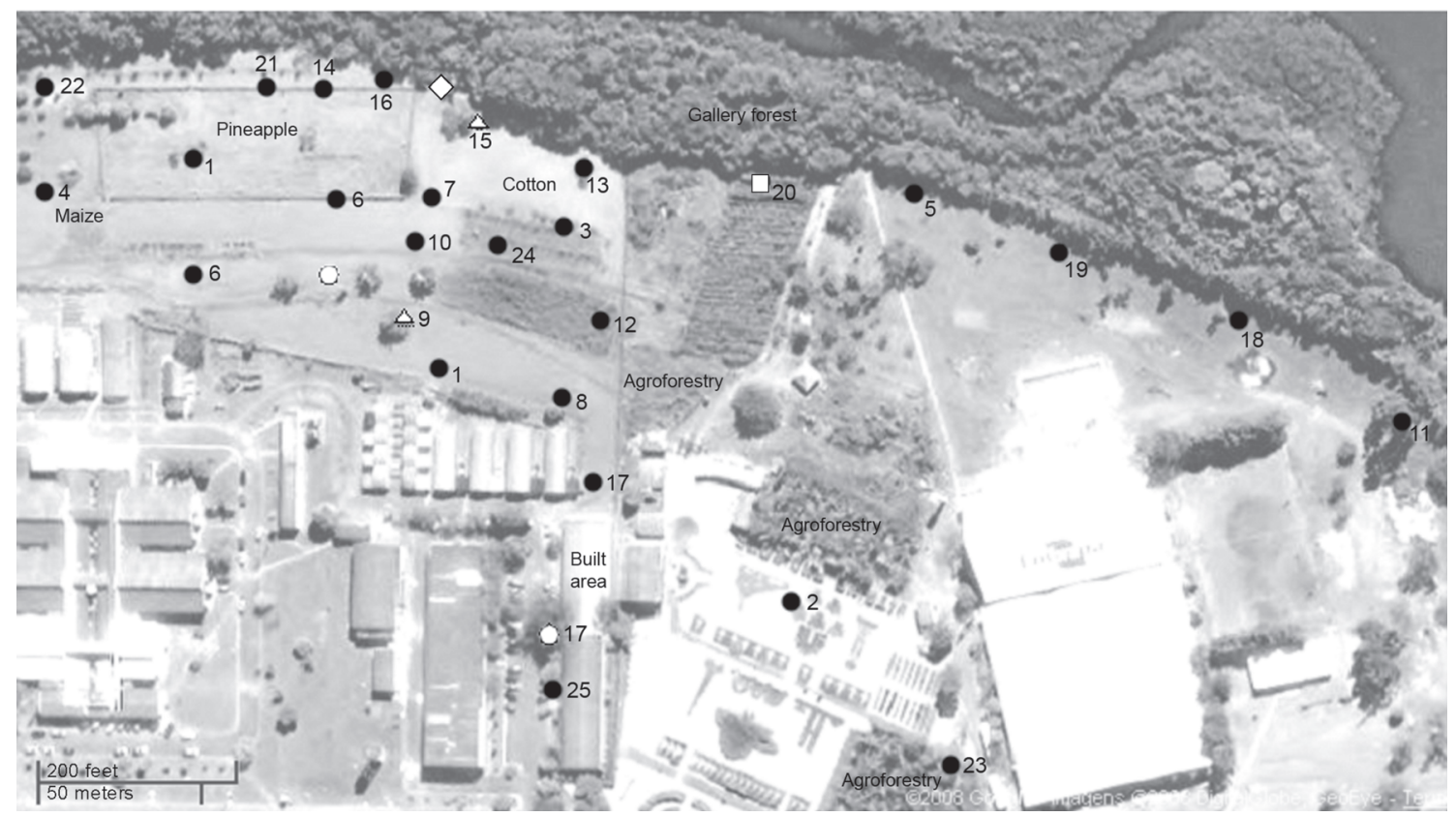

Figure 1. Trails distribution of L. praedator $(\bullet)$ in aerial image of Cenargen, Brasília. Reuses of abandoned army ants trails are indicated by the following symbols: $(\square)$ Neivamyrmex sp., $(\triangle)$ Labidus coecus, $(\bigcirc)$ Eciton vagans $(\diamond)$ Eciton hamatum. Repeated trail numbers are eight-hour observations in the same date.

Table I. Trail chemical opportunism between army ants and temporal occurrence (Embrapa Cenargen, Brasília). Same or consecutive dates are indicative of linear distances between colonies or foraging radius around bivouac. Point references are plotted in figure 1. Primarily observed species or trail oportunist: : (Lp) L. praedator, (Lc) L. coecus, (Ev) Eciton vagans, (Eh) E. hamatum, (Ne) Nomamyrmex esembeckii, (N) Neivamyrmex sp. For trail number reference see figure 1.

\begin{tabular}{|c|c|c|c|c|c|c|c|c|c|}
\hline $\begin{array}{c}\text { Trail } \\
\text { number }\end{array}$ & Date of record & $\begin{array}{l}\text { Observed } \\
\text { species }\end{array}$ & $\begin{array}{c}\text { Trail reuse } \\
\text { date }\end{array}$ & $\begin{array}{l}\text { Opportunistic } \\
\text { species }\end{array}$ & $\begin{array}{c}\text { Trail } \\
\text { number }\end{array}$ & Date of record & $\begin{array}{l}\text { Observed } \\
\text { species }\end{array}$ & $\begin{array}{c}\text { Trail reuse } \\
\text { date }\end{array}$ & $\begin{array}{l}\text { Opportunistic } \\
\text { species }\end{array}$ \\
\hline 1 & $29 / 1$ & Lp & & & 15 & 14-9/IV & Lp & $6 / \mathrm{V}$ & Lc \\
\hline 2 & $29 / 1$ & Lp & & & 16 & 14/IV-6/V & Lp & & \\
\hline 3 & $11 / I I$ & Lp & & & 17 & 15-16/IV & Lp & $17 / I V$ & Ev \\
\hline 4 & $21 / I 1$ & $L p$ & & & 18 & 19/IV & Lp & & \\
\hline 5 & $1 / I I I$ & Lp & & & 19 & $21 / \mathrm{IV}$ & Lp & & \\
\hline 6 & $2 / I I I$ & Lp & & & 20 & $27 /$ IV-4-17/V & Lp & $24 / \mathrm{V}$ & $\mathrm{N}$ \\
\hline 7 & $3 / I I I$ & Lp & & & 21 & $4 / \mathrm{V}$ & Lp & & \\
\hline 8 & $4 / I I I$ & Lp & & & 22 & $14 / \mathrm{V}$ & Lp & & \\
\hline 9 & $5-16 / I I I$ & Lp & $18 / I I I$ & Lc & 23 & $21 / \mathrm{VI}$ & Lp & & \\
\hline 10 & $9-24 / I I I$ & Lp & & & 24 & $21 / \mathrm{VI}$ & Lp & & \\
\hline 11 & 14/III-6/IV-17/IV-21/IV & Lp & & & 25 & $22 / \mathrm{VI}$ & Lp & & \\
\hline 12 & $15 / I I I$ & Lp & & & $\mathrm{O}$ & $29 / 1$ & Ev & $30 / 1$ & Lp \\
\hline 13 & $16 / I I I$ & Lp & & & $\mathrm{O}$ & $12 / I I I$ & Eh & $13 / I I I$ & $\mathrm{Ne}$ \\
\hline 14 & $13 / \mathrm{IV}-2 / \mathrm{V}$ & $L p$ & & & & & & & \\
\hline
\end{tabular}

Colonies of $L$. praedator moved an average linear distance of about $60 \mathrm{~m} /$ day around the bivouac in the stationary phase for foraging (points 6, 7, 8 and 9, 10 and 12, 18 and 19 of figure
1) and about 100 meters/day (points 1 of figure 1) for dispersion in the nomadic phase. They passed from at least 11 to 38 days exploring the same trail for foraging during the stationary phase. 

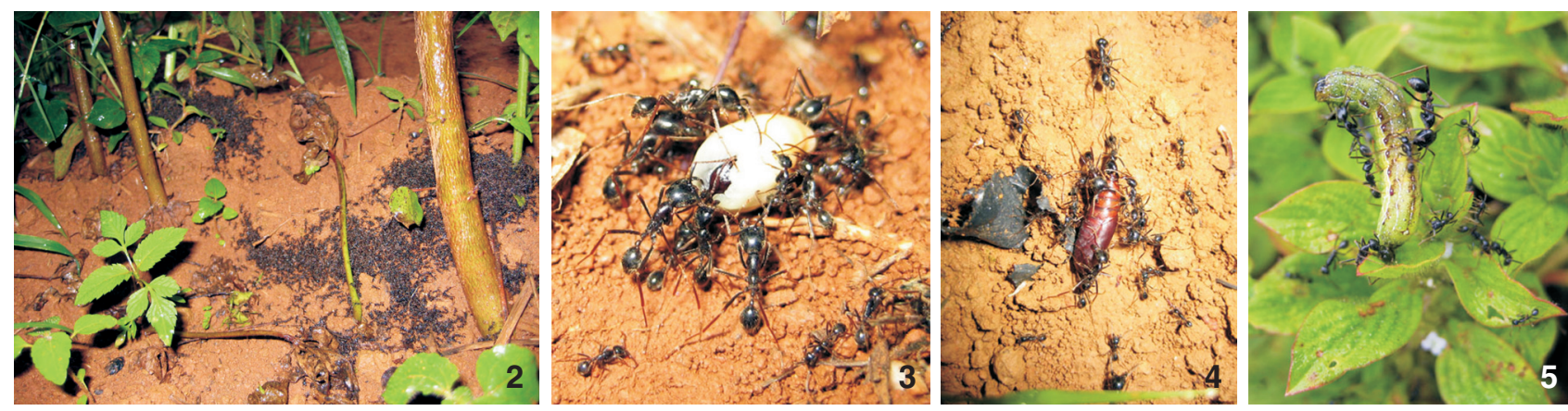

Figures 2-5. Two mantle shields against rain of L. praedator and some diet items of their colonies (Embrapa Cenargen, Brasilia). From left to right: aggregations of hundreds of individuals of $L$. praedator after heavy rain, under patches covered by a series of poorly developed cotton plants (2); ariled seeds of Matayba guianensis (3), pupa of A. argillacea (4) and Lepidopteran caterpillar (5) transported by L. praedator in the studied area.

During intense rainfall, swarm-raiding majors and workers aggregated in groups of hundreds of ants under cotton shrubs (Fig. 2) or even under leaf-litter, using these patches as refuges. One colony of these ants was found at least $170 \mathrm{~m}$ from a gallery forest edge in an agroforestry system (Point 23 of figure 1). The trails of $L$. praedator transverse a mosaic of habitats and occur above the litter or shaded concrete and, in addition, underneath soil surface, Brachiaria grass straw or herbaceous weeds.

Swarm raid area for $L$. praedator varied from $16 \mathrm{~m}^{2}$ in a dry season on bare soil to $25 \mathrm{~m}^{2}$ in a wet season under a mango tree. Most prey end up encircled by these ants in different vegetation strata. Prey become more vulnerable as can be subject to L. praedator attacks in addition to opportunistic predation by swarm followers. Some ants were observed climbing weeds or crops up to a height of $1.3 \mathrm{~m}$, whereas others in greater densities patrolled the soil surface and captured running or falling prey. The foraging of groups of the smoothbilled anim Crotophaga ani Linnaeus, 1758 was highly associated to $L$. praedator active swarm raids in the studied agroecosystem.

Other animals, such as flies (Diptera: Sarcophagidae: Sarcophaginae) and wasps (Hymenoptera: Vespidae: Polistinae), were observed following $L$. praedator swarm raids. These animals approached aggressively prey immobilized or transported by $L$. praedator. A wasp moving near a captured caterpillar was also subdued by L. praedator.

Colonies of $L$. praedator exploited the cotton plantation during the 2007 and 2008 summer seasons and even formed a bivouac inside the cotton plot. The boll weevil (Coleoptera: Curculionidae) was the main diet item in the insecticide-free cotton, as opposed to pupae of the cotton leafworm in insecticide treated plot (Lepidoptera: Noctuidae) (Tab. II and Figs 35). After $L$. praedator captured some large prey, they dismembered and sectioned them in order to overcome resistance strategies to ant attack. Pre-pupae of fall armyworm (Lepidoptera: Noctuidae) were captured and transported almost intact back to the bivouac. Lagria villosa Fabricius, 1783 (Coleoptera: Lagriidae) adults were not preyed by these ants, probably due to the rigidity of their exoskeleton and flying capacity, although it was observed the predation of their larva by ants.

Besides the invertebrates, L. praedator exploited or transported to bivouac some plant materials such as flowers or diaspores of weeds and fruit aril and flesh of tree species (Tab. II and Figs 3-5).

\section{DISCUSSION}

In general, the opportunistic use of trail odor by another species of Ecitoninae seems to occur immediately after the trail is abandoned by the army ant species that deposited the trail pheromone. Four reused trails led the opportunistic species to recently abandoned bivouac sites. A similar, chemically-based interaction exists for two arboreal ant species: Cephalotes sp. used Azteca sp. trail pheromones to locate food sources patches in Rhizophora mangle (Linnaeus, 1753) trees in mangrove forests, an interaction named information parasitism (ADAMs 1990).

In our observations, there is no damage to colony nutrition of the species releasing information, and we suggest the term chemical opportunism for this type of interaction - which is advantageous at least to the opportunistic species. The location of appropriate bivouacs in open areas through chemical and vibration from walking signals can be one of the reasons for the evolution of this interaction. In these areas, the most soil surface is exposed to high temperatures and agricultural disturbances. In addition, ants of the tribe Attini defend their subterranean tunnels and chambers. So most Attini nesting structures - potential army ants nesting sites - can be unavailable. This makes the evolution of a common strategy for bivouac location another trait that can also explain the evolutionary success of army ants.

The decoding of army ants species-specific mechanical vibrations on trail can be the main explicative mechanism for which the opportunistic species avoid using still occupied army

Revista Brasileira de Zoologia 25 (4): 674-681, December, 2008 
Table II. Diet composition of L. praedator recorded in three foraging columns in the experimental area of Embrapa Cenargen (Brasília) on cotton plots surrounded by weeds strips in six hours of observation: 13/V/2007, 03/III/2008, and 09/III/2008.

\begin{tabular}{|c|c|c|c|}
\hline Diet composition & Taxonomic category & Type & Number of itens \\
\hline \multicolumn{4}{|l|}{ Arthropoda } \\
\hline \multicolumn{4}{|l|}{ Hemiptera: Pentatomidae } \\
\hline Red shouldered stink Bug & Thyanta sp. & Adult & 1 \\
\hline Southern green stink bug & Nezara viridula Linnaeus, 1758 & Adult & 3 \\
\hline Stink bug & Not identified & Nymph & 3 \\
\hline \multicolumn{4}{|l|}{ Hemiptera: Cercopidae } \\
\hline Spittlebug & Mahanarva sp. & Adult & 1 \\
\hline Spittlebug & Mahanarva sp. & Nymph & 3 \\
\hline \multicolumn{4}{|l|}{ Hemiptera: Cicadellidae } \\
\hline Leafhopper & Not identified & Adult & 2 \\
\hline Leafhopper & Not identified & Nymph & 4 \\
\hline \multicolumn{4}{|l|}{ Lepidoptera: Noctuidae } \\
\hline Fall armyworm & Spodoptera frugiperda (Smith, 1797) & Larvae & 7 \\
\hline Armyworm & Spodoptera cosmioides (Walk., 1858) & Larvae & 3 \\
\hline Soybean Looper & Pseudoplusia includens (Walker, 1857) & Larvae & 4 \\
\hline Tobacco budworm & Heliothis virencens (Fabricius, 1781) & Larvae & 2 \\
\hline Cotton leafwom & Alabama argillacea (Hübner, 1823) & Larvae & 6 \\
\hline Cotton leafwom & Alabama argillacea & Pupae & 5 \\
\hline Caterpillars $(<2 \mathrm{~cm})$ & Not identified & Larvae & 21 \\
\hline Caterpillars & Not identified & Pieces & 37 \\
\hline \multicolumn{4}{|l|}{ Coleoptera: Curculionidae } \\
\hline Boll weevil & Anthonomus grandis (Boheman, 1843) & Larvae & 3 \\
\hline Boll weevil & Anthonomus grandis & Pupae & 2 \\
\hline Boll weevil & Anthonomus grandis & Adult & 5 \\
\hline \multicolumn{4}{|l|}{ Hymenoptera } \\
\hline Ant & Formicidae & Adult & 1 \\
\hline Wasp & Vespidae & Adult & 1 \\
\hline \multicolumn{4}{|l|}{ Orthoptera } \\
\hline Grasshopper & Not identified & Adult & 1 \\
\hline \multicolumn{4}{|l|}{ Dermaptera } \\
\hline Earwig & Not identified & Adult & 3 \\
\hline \multicolumn{4}{|l|}{ Isopoda } \\
\hline Woodlouse & Not identified & Adult & 3 \\
\hline \multicolumn{4}{|l|}{ Areneidae } \\
\hline Spider & Not identified & Adult & 1 \\
\hline \multicolumn{4}{|l|}{ Angiospermae } \\
\hline \multicolumn{4}{|l|}{ Poaceae } \\
\hline Signalgrass & Brachiaria sp. & Diaspore & 8 \\
\hline \multicolumn{4}{|l|}{ Arecaceae } \\
\hline African oil palm & Elaeis guineensis Jacq. 1763 & Pulp & 4 \\
\hline \multicolumn{4}{|l|}{ Asteraceae } \\
\hline Lilac tasselflower & Emilia sonchifolia (Linnaeus) DC, 1834 & Diaspore & 3 \\
\hline \multicolumn{4}{|l|}{ Labiatae } \\
\hline \multirow[t]{2}{*}{ Wild spikenard } & Hyptis suaveolens (Linnaeus) Poit, 1806 & Flowers & 4 \\
\hline & Hyptis suaveolens & Diaspore & 2 \\
\hline \multicolumn{4}{|l|}{ Sapindaceae } \\
\hline Matayba & Matayba guianensis Aubl & Aril & 14 \\
\hline
\end{tabular}


ants trails. A lack of trail odor specificity seems to be common in Ecitoninae ants. Four species of Neivamymex and L. coecus followed each other's trail in the laboratory (WATKINS 1967). Army ants reuse of abandoned trails can involve two chemical components: one generic, to which all army ants respond, and another that is genus or species-specific (Togerson \& AKre 1970). Evidence suggests that trail pheromone for L. praedator, L. coecus and $E$. burchelli is the same substance called skatole, although the effect of this substance on army ant behavior was not tested (KeEgans et al. 1993).

This type of chemically-based interaction also seems to occur in $L$. praedator swarm raids. The army ant recruitment pheromone deposited on prey can attract flies and wasps for ant-attacked caterpillars, but not transported by L. praedator. The quantitative contribution of army ant followers in reducing arthropod densities after raiding swarms passage and the exact stimuli that facilitate prey location by flies and wasps, are aspects that deserve further study.

Sarcophagine flies are facultative parasitoids of earthworms, terrestrial gastropods, Lepidoptera, and Orthoptera and can be coprophagous or necrophagous. In some species, there is a facultative exchange of necrophagous and parasitoid strategies. Adults can both feed on flowers and be attracted to animal carcasses or organic matter in decomposition. Larvae are predators or parasitoids of other invertebrates (Coupland \& BARKER 2004). Some Sarcophaginae species are parasitoids of pests such as Oiketicus kirbyi Guilding, 1827 (Lepidoptera: Psychidae) larvae (Gold et al. 2002), Spodoptera litura Fabricius, 1775 (Lepidoptera: Noctuidae) pupae (Sitaramaiah et al. 2001) and Mocis Hubner, 1823 (Lepidoptera: Noctuidae) pre-pupae (Hall 1985). Polistinae wasps are generalist predators, mainly of Lepidoptera (Prezoto et al. 2006).

Labidus sp. seems to choose bivouac sites beside fruiting trees that provide sometimes an abundant and predictable food source and eventually elevated bivouac sites to escape surface inundation in agroecosystems. Labidus was found in the canopy of Attalea phalerata Mart. (Arecaceae) in the Pantanal (BatTirola et al. 2005) and around Elaeis guineensis Jacq. (Arecaceae) in the studied area.

The caterpillars were the main item transported by $L$. praedator in our samples in this agroecosystem. This fact is probably due to a greater abundance of Lepidoptera in the cultivated areas explored by its swarm raids. In other agroecosystems Labidus sp. was related hunting pests such as Sitophylus sp. (Coleoptera: Curculionidae) (CAETANo 1991) and Diaphania sp. (Lepidoptera: Pyralidae) (GonkING et al. 2003). Cockroaches (Insecta: Blattodea) and spiders (Arthropoda: Araneae) were the dominant items of L. praedator diet in "terra firme" tropical rain forest (VIEIRA \& HÖFER 1994). Diet composition of $L$. praedator seems to be determined to the more abundant prey. This varies with microhabitat type and year season. Greater samples before and after $L$. praedator swarm raids are needed in order to understand the effect of this army ant predation on invertebrate communities.
Before the recorded cleaning of seeds of Matayba guianensis Aubl. (Sapindaceae) by Labidus in the studied cerrado gallery forest, there were records of cleaning of fruits of Clusia criuva Cambess (Clusiaceae) in a Restinga (Passos \& Oliveira 2003), Syagrus romanzoffiana (Cham.) Glassman (Arecaceae) in an Atlantic Rainforest (ZARA et al. 2003) and Caryocar brasiliense Camb. (Caryocararaceae) in the Cerrado (Powell \& BAKer 2008). If pulp or aril removal by ants increases germination success of some plant species (Pizo \& Oliveira 2000) and if seedling survival increases at greater distances from mother-plant (HyaTt et al. 2003), L. praedator colonies perform a role as seed dispersers that still has not been studied. We hypothesize that smaller weed seeds have their germination frustrated because of underground transport by Labidus sp.

The occurrence and richness of Neivamymex spp.- with hipogaeic habit - and of Eciton spp.- with nocturnal habit - were underestimated. Future studies aiming to describe army ant community structure should combine standardized trail-walk surveys in different periods of day with buried attractive traps.

Labidus praedator colonies uses field margins - with grasses, leguminous and weeds strips - around cultivated area are as refuges, mini-corridors and rich food patches. Rain or irrigation water and shade provided by soil covers reduce microclimatic variations and provide optimal conditions for incursions from the gallery forest into adjacent agroecosystem. However, the potential beneficial role of $L$. praedator in pest control will only be possible by fragment forest conservation - a source of migrant predators and pollinators and a possible dry season refuge (Marco Jr \& Coelho 2004, Guerra Sobrinho \& Shoereder 2007).

Sarcophaginae flies and polistinae wasps were recorded disputing caterpillars with $L$. praedator in aggressive or opportunistic interactions possibly for the first time. The most document interspecific interactions of army ants during swarm raid are with birds (WILlis \& ONIKI 1992, RoberTs et al. 2000b) and with marmosets (MELo JunIOR \& ZARA 2007), although Tachinidae and Conopidae flies were common army ants followers (Gotwald 1982).

Due to the large size of their colonies and their corresponding nutrition and mobility demands, L. praedator can have a significant impact on invertebrate density and diversity in agroecosystems and act as an agent of conservative biological control. The conservative biological control involves the maintenance or creation of favorable habitat for feeding, reproduction and early colonization by assemblies of native generalist natural enemies with the aim of increase the persistence of them in cropping systems (BARBosa 1998). In order to quantify L. praedator action in pest control, management practices in agroecosystems should increase its habitat complexity and reduce disturbance regimes.

\section{ACKNOWLEDGMENTS}

We are grateful to João B. Bringel from Herbarium of Cenargen for the tree species identification, Cátia A. de Mello- 
Patiu from Departamento de Entomologia, Museu Nacional, UFRJ for the identification of Diptera subfamily and to Jacques Delabie and to Ivan Cardoso do Nascimento from Centro de Pesquisas do Cacau, CEPLAC for the identification of army ants.

\section{LITERATURE CITED}

ADAMs, E.S. 1990. Interaction between the ants Zacryptocerus maculatus and Azteca trigona: Interspecific parazitation of information. Biotropica 22: 200-206.

Barbosa, P. 1998. Conservation biological control. San Diego, Academic Press, 396p.

BRADY, S.G. 2003. Evolution of the army ant syndrome: the origin and long-term evolutionary stasis of a complex of behavioral and reproductive adaptations. Proceedings of the National Academy of Sciences 100: 6575-6579.

Battirola, L.D.; M.I. Marques; J. Adis \& J.H.C. Delabie. 2005. Composição da comunidade de Formicidae (Insecta, Hymenoptera) em copas de Attalea phalerata Mart. (Arecaceae), no Pantanal de Poconé, Mato Grosso, Brasil. Revista Brasileira de Entomologia 49 (1): 107-117

Caetano, F.H. 1991. Ocorrência de formigas correição, Labidus praedator (Hymenoptera, Ecitoninae) atacando o gorgulho do milho (Sitophylus sp). Anais da Sociedade Entomológica do Brasil 20 (2): 453-455.

Coupland, J.B. \& G.M. Barker. 2004. Diptera as predators and parasitoids of terrestrial gastropods, with emphasis on Phoridae, Calliphoridae, Sarcophagidae, Muscidae and Fanniidae (Diptera, Brachycera, Cyclorrhapha), p. 85-158. In: G.M. BARKER (Ed.). Natural enemies of terrestrial molluscs. Wallingford, CAB International, 644p.

Fowler, H.G. 1979. Notes on Labidus praedator (Fr. Smith) in Paraguay (Hymenoptera: Formicidae: Dorylinae: Ecitonini). Journal of Natural History 13: 3-10

Gallo, D.; O. Nakano; S. Silveira Neto; R.P.L. Carvalho; G.C. Baptista; E. Berti Filho; J.R.P. Parra; R.A. Zucchi; S.B. Alves; J.D. Vendramim; L.C. Marchini; J.R.S. Lopes \& C. OMOto. 2002. Entomologia agrícola. Piracicaba, FEALQ, 920p.

Gold, C.S.; B. Pinese \& J.E. PeÑA. 2002. Pests of banana, p. 1356. In: J.E. PeÑa; J.L. Sharp \& M. Wysoki (Eds). Tropical fruit pests and pollinators: biology, economic importance, natural enemies and control. Wallingford, CABI Publishing, 448p.

Gonring, A.H.R.; M.C. Picanço; J.C. Zanuncio \& A.A. Semeão. 2003. Natural biological control and key mortality factors of the pickleworm, Diaphania nitidalis Stoll (Lepidoptera: Pyralidae), in cucumber. Biological Agriculture \& Horticulture 20: 365-380.

Gotwald, W.H. 1982. Army ants, p. 157-254. In: H.R. Hermann (Eds). Social Insects. New York, Academic Press, vol. 4, 385p.

Gotwald, W.H. 1995. Army ants: the biology of social predation. Ithaca, Cornell University Press, 302p.

Guerra Sobrinho, T. \& J.H. Schoereder. 2007. Edge and shape effects on ant (Hymenoptera: Formicidae) species richness and composition in forest fragments. Biodiversity and Conservation 16: 1459-1470.

HaLL, D.G. 1985. Parasitoids of grasslooper prepupae and pupae in south florida sugarcane. Florida Entomologist 68 (3): 486-487

Hölldobler, B. \& E.O. Wilson. 1990. The ants. Cambridge, Harvard University Press, 732p.

Hyatt, L.A.; M.S. Rosenberg; T.G. Howard; G. Bole; W. Fang; J. Anastasia; K. Brown; R. Grella; K. Hinman; J.P. Kurdziel \& J. Gurevitch. 2003. The distance dependence prediction of the Janzen-Connell hypothesis: a meta-analysis. Oikos 103: 590602.

Kaspari, M. \& S. O’Donnell. 2003. High rates of army ant raids in the Neotropics and implications for ant colony and community structure. Evolutionary Ecology Research 5: 933-939

Keegans, S.J.; J. Billen; E.D. Morgan \& O.A. GökCen. 1993. Volatile glandular secretions of three species of New World army ants, Eciton burchelli, Labidus coecus and Labidus praedator. Journal of Chemical Ecology 19: 2705-2719

Kissmann, K.G. \& D. Groth. 1997. Plantas infestantes e nocivas. São Paulo, BASF Brasileira, $2^{\text {nd }}$ ed., vols. 1-3, 2524p.

Kumar, A. \& S. O'Donnell. 2007. Fragmentation and elevation effects on bird-army ant interactions in Neotropical montane forest of Costa Rica. Journal of Tropical Ecology 23: 581-590.

Lopes, H.S. 1973. Collecting and rearing Sarcophagid flies (Diptera) in Brazil, during forty years. Anais da Academia Brasileira de Ciências 45: 279-291.

LoRenZI, H. 1991. Plantas Daninhas do Brasil: terrestres, aquáticas, parasitas, tóxicas e medicinais. Nova Odessa, Editora Plantarum, $2^{\text {nd }}$ ed., $440 \mathrm{p}$.

LoRENZI, H. 1994. Manual de Identificação e Controle de Plantas Daninhas: plantio direto e convencional. Nova Odessa, Editora Plantarum, $4^{\text {th }}$ ed., 299p.

Marco Jr, P. \& F.M. Coelho. 2004. Services performed by the ecosystem: forest remnants influence agricultural cultures's pollination and production. Biodiversity and Conservation 13: $1245-1255$.

Martins, M.M. 2000. Foraging over army ants by Callithrix aurita (Primates: Callitrichidae): Seasonal occurence? Revista de Biologia Tropical 48 (1): 261-262.

Meisel, J.E. 2006. Thermal ecology of the Neotropical army ant, Eciton burchelli. Ecological Applications 16 (3): 913-922.

Melo Junior, T.A. \& F.J. Zara. 2007. Black-tufted-ear Marmoset Callithrix penicillata (Primates: Callitrichidae) Following the Army Ant Labidus praedator (Formicidae: Ecitoninae) in the Cerrado and the Atlantic Forest, Brazil. Neotropical primates 14 (1): 32-33.

O’Donnell, S.; J. Lattke; S. Powell \& M. Kaspari. 2007. Army ants in four forests: geographic variation in raid rates and species composition Journal of Animal Ecology 76: 580-589.

Otis, G.W.; C.S. Santana; D.L. Crawford \& M.L. Higgins. 1986. 
The Effect of Foraging Army Ants on Leaf-Litter Arthropods. Biotropica 18 (1): 56-61.

Passos, L. \& P.S. Oliveira. 2003. Interaction between ants fruits and seeds in restinga Forest in South-Eastern Brazil. Journal of Tropical Ecology 19: 261-270.

Pizo, M.A. \& P.S. Oliveira. 2000. The Use of Fruits and Seeds by Ants in the Atlantic Forest of Southeast Brazil. Biotropica 32 (4): 851-861

Powell, S. \& B. BAKer. 2008. Os grandes predadores dos neotrópicos: comportamento, dieta e impacto das formigas de correição (Ecitoninae), p. 18-37. In: E. F.VILELA; I.A. DOS SANTOS; J.E. SERRÃo; J.H. SChOEREder; J. LiNo-Neto \& L.A. DE O. CAMPOS (Eds). Insetos sociais da biologia à aplicação. Viçosa, Universidade Federal de Viçosa, 442p.

Prezoto, F.; H.H. Santos-Prezoto; V.L.L. Machado \& J.C. Zanuncio. 2006. Prey captured and used in Polistes versicolor (Olivier) (Hymenoptera:Vespidae) Nourishment. Neotropical Entomology 35 (5): 707-709

Ribeiro, J.F.; C.E.L. FonseCa \& J.C.S. SiLva. 2001. Cerrado: caracterização e recuperação de matas de galeria. Planaltina, Embrapa Cerrados, 899p.

Roberts, D.L.; R.J. Cooper \& L.J. Petit. 2000a. Use of Premontane Moist Forest and Shade Coffee Agroecosystems by Army Ants in Western Panama. Conservation Biology 14 (1):192-199.

Roberts, D.L.; R.J. CoOper. \& L.J. Petit. 2000b. Flock characteristics of ant-following birds in premontane moist forest and coffee agroecosystems in western Panama. Ecological Applications 10: $1414-1425$.

SARAN, P.E. \& W.J. SANTOS. 2007. Manual de pragas do algodoeiro. Campinas, FMC Agrícola, 300p.

Submitted: 09.IV.2008; Accepted: 28.XI.2008.

Editorial responsibility: Marcio R. Pie
Silvie, P.; J. Belot; B. Michel; E. Takizawa; G.D. Busarello \& D. Thomazoni. 2007. Manual de identificação das pragas e seus danos no cultivo do algodão. Cascavel, COODETEC, Boletim Técnico 34, 120p.

Sitaramaiah, S.; S.G. Rao; G. Ramaprasad \& U. Sreedhar. 2001. Role of Biological Control Agents in Tobacco Insect Pest Management, p. 389-400. In: K. Upadhyaya; K.G. Mukerji \& B.P Chamola (Eds). Biocontrol potential and its exploitation in sustainable Agriculture. New York, Kluwer Academic/Plenum publishers, vol. 2, 434p.

VieIRA, R.S. \& H. HöFer. 1994. Prey spectrum of two army ant species in central Amazonia, with special attention on their effect on spider populations. Andrias 13: 189-198.

Togerson, R.L. \& R.D. Akre. 1970. The persistence of army ant chemical trails and their significance in the Ecitonie-Ecitophile association (Formicidae: Ecitonini). Melanderia 5: 1-28.

WATKINS, J.F.; T.W. ColE \& R.S. BALDRIDGE. 1967. Laboratory studies on interspecies trail following and trail preference of army ants (Dorylinae). Journal of the Kansas Entomological Society 40: 146-151.

Willis, E.O. \& Y. ONIKI. 1992. As aves e as formigas de correição. Boletim do Museu Paraense Emílio Goeldi, Série Zoologia, 8: 123-215.

Wrege, P.H.; M. Wikelski; J.T. Mandel; T. Rassweiler \& I.D. Couzin. 2005. Antbirds parasitize foranging army ants. Ecology 86 (3): 555-559.

Zara, F.J.; M.S.C. Morini \& L.M. Kato. 2003. New record for the army ants Labidus mars (Formicidae: Ecitoninae) in Atlantic Rain Forest in São Paulo State, Brazil. Sociobiology 42 (2): 443-448. 